\title{
Upaya Penguatan Kompetensi Kewilayahan Masyarakat Melalui Pemetaan Partisipatif pada Warga Kelurahan Lomanis, Cilacap Tengah, Cilacap
}

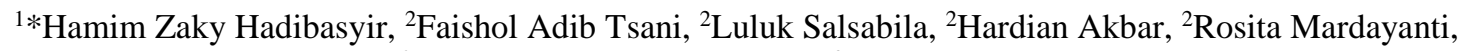 \\ ${ }^{2}$ Grezia Eleganza Nur Pradani, ${ }^{3}$ Ratna Yudhiyati \\ ${ }^{1}$ Mahasiswa Sarjana Fakultas Geografi, Universitas Gadjah Mada \\ ${ }^{2}$ Mahasiswa Sarjana Fakultas Ilmu Sosial dan Ilmu Politik, Universitas Gadjah Mada \\ ${ }^{3}$ Mahasiswa Sarjana Fakultas Ekonomika dan Bisnis, Universitas Gadjah Mada \\ *Penulis korespondensi, email: hamim.zaky.h@mail.ugm.ac.id
}

(Received: 1 July 2020/Accepted: 6 July 2020/Published: 7 July 2020)

\begin{abstract}
Abstrak
Upaya pemberdayaan masyarakat dalam rangka peningkatan kompetensi kewilayahan dilaksanakan di Kelurahan Lomanis, Kecamatan Cilacap Tengah, Kabupaten Cilacap, Jawa Tengah. Berdasarkan observasi dan wawancara dengan warga setempat, diperoleh informasi mengenai permasalahan-permasalahan yang ada. Pertama, di kantor Kelurahan Lomanis pada tahun 2013 belum terdapat peta-peta baik peta dasar maupun peta tematik yang dapat menunjang berbagai analisis kewilayahan. Kedua, sebagian warga baik para pemuda maupun anak-anak, ada yang masih belum memahami orientasi arah dan lokasi relatif kelurahan Lomanis di dalam Kabupaten Cilacap. Ketiga, beberapa data tematik seperti komposisi penduduk dan tingkat partisipasi balita dalam pos pelayanan terpadu (posyandu) belum divisualisasikan dengan peta. Oleh karena itu, kegiatan pemberdayaan ini dilakukan dalam bentuk pemetaan partisipatif untuk pengadaan peta dasar yang berupa peta administrasi dan peta tematik berupa peta komposisi penduduk dan peta tingkat partisipasi balita dalam posyandu yang nantinya dipajang di kantor kelurahan. Selain itu juga dilakukan lomba mengenal Cilacap dan Negara Kesatuan Republik Indonesia (NKRI) melalui peta guna penanaman kompetensi kewilayahan sejak dini. Semua kegiatan pemetaan partisipatif berjalan lancar. Adanya peta dasar yang memuat batas Rukun Warga $(R W)$ dan peta-peta tematik lainnya memudahkan warga dan pemangku kepentingan lainnya dalam memahami kondisi wilayahnya. Proses pelibatan pembuatan peta secara partisipatif telah mengasah kompetensi kewilayahan warga setempat. Adapun kegiatan penguatan kompetensi kewilayahan pada anak-anak telah berjalan dengan lancar melalui kegiatan lomba mengenal Cilacap dan NKRI melalui peta. Selepas kegiatan, anak-anak di lokasi pemberdayaan semakin menyadari akan potensi dan dinamika wilayah yang ada di Kabupaten Cilacap dan Indonesia.
\end{abstract}

Kata Kunci : pemetaan partisipatif, kompetensi kewilayahan, peta dasar, peta tematik, Lomanis Abstract
Community empowerment efforts to enhance regional competence were carried out in Lomanis
Village, Cilacap Tengah District, Cilacap Regency, Central Java. There were several problems
in the area. First, in the Lomanis Village's office in 2013 there were no maps either base maps
or thematic maps that could support various regional analyses. Second, there are some residents,
both young people and children, who still do not understand the orientation of the direction and
relative location of the Lomanis village in Cilacap Regency. Third, some thematic data had not
been visualised using maps. Therefore, this empowerment activity was carried out in the form of
participatory mapping for to create a base map and thematic maps to be hanged in the village
office. In addition, there was also a competition to get to know Cilacap and the Republic of
Indonesia (NKRI) through maps for children. All participatory mapping activities went smoothly. 
The presence of a base map that contains boundaries of the neighbourhood (rukun warga/RW) and other thematic maps makes it easy for residents and other stakeholders to appreciate the condition of the area. The participatory map-making process has honed the regional competence of local residents. The regional competence strengthening activities for children have run smoothly through the competition of getting know Cilacap and NKRI through maps. After the activities, children in the location of empowerment were increasingly aware of the potential and dynamics of the region in Cilacap Regency and Indonesia.

Keywords: participatory mapping, regional competence, base map, thematic map, Lomanis

\section{Pendahuluan}

Wilayah kegiatan pemberdayaan masyarakat berlokasi di Kelurahan Lomanis, Kecamatan Cilacap Tengah, Kabupaten Cilacap, Provinsi Jawa Tengah. Lomanis terdiri atas 6 Rukun Warga (RW) dengan luas wilayah 362 ha. Kelurahan Lomanis berbatasan dengan beberapa kelurahan lainnya. Bagian utara Kelurahan Lomanis berbatasan dengan Kelurahan Karangtalun, bagian selatan berbatasan dengan Kelurahan Donan, bagian barat berbatasan dengan Kelurahan Kutawaru, dan bagian timur berbatasan dengan Kelurahan Donan (Gambar 6).

Kelurahan Lomanis pada dasarnya bukan merupakan wilayah kelurahan paling sempit di Kabupaten Cilacap, namun luasan areal permukiman yang ada di kelurahan Lomanis adalah yang paling sempit diantara kelurahan-kelurahan lain yang ada di kabupaten Cilacap. Merujuk pada data BPS Cilacap (2014), kepadatan penduduk di Lomanis tahun 2013 yaitu $1.359 \mathrm{jiwa} / \mathrm{km}^{2}$, sedangkan kelurahan tetangganya seperti Donan, Sidanegara, dan Gunungsimping memiliki kepadatan penduduk $5.369 \mathrm{~km}^{2}, 8.953 \mathrm{~km}^{2}$, dan $6.557 \mathrm{~km}^{2}$, secara berturut-turut. Hal ini disebabkan oleh sebagian besar wilayah Lomanis yang mengalami perubahan penggunaan lahan dari yang semula permukiman menjadi kawasan industri. Industri yang paling banyak menggunakan ruang di kelurahan Lomanis adalah Pertamina. Namun, kelurahan Lomanis juga merupakan ring satu dari kawasan industri pabrik semen Holcim. Sawah juga mudah dijumpai di Kelurahan Lomanis, tapi pemilik lahannya cenderungnya merupakan bukan warga local, namun orang luar (Ekaputri, 2014).

Berada di dekat dua industri nasional merupakan sesuatu yang memiliki keuntungan dan kekurangan. Keuntungannya yaitu munculnya peluang usaha baru untuk membuka warung makan dan hunian untuk para karyawan industri yang bekerja di salah satu industri tersebut. Selain itu, warga Lomanis juga memiliki peluang untuk mengajukan permohonan dana melalui anggaran Corporate Social Responsibility (CSR) yang dimiliki dua perusahaan besar tersebut. Adapun kerugiannya yaitu kualitas lingkungan berpotensi menurun dan kesehatan warga dapat terganggu mengingat adanya potensi pencemaran limbah pabrik dan polusi udara yang dihasilkan oleh industri.

Berdasarkan hasil observasi dan wawancara kepada beberapa warga dan tokoh masyarakat Lomanis, diperoleh beberapa permasalahan yang membutuhkan penanganan segera. Pertama, di kantor Kelurahan Lomanis pada tahun 2013 belum terdapat peta-peta baik peta dasar maupun peta tematik yang dapat menunjang berbagai analisis kewilayahan. Kedua, sebagian warga baik para pemuda maupun anak-anak, ada yang masih belum memahami orientasi arah dan lokasi relatif kelurahan Lomanis di dalam Kabupaten Cilacap. Ketiga, beberapa data tematik seperti komposisi penduduk dan tingkat partisipasi balita dalam pos pelayanan terpadu (posyandu).

Terkait masalah mengenai belum adanya peta-peta dasar maupun tematik di kantor kelurahan Lomanis membutuhkan penanganan segera karena beberapa hal. Peta dasar seperti peta adminsitrasi skala besar (detil) yang di dalamnya memuat batas RW dan posisi dan posisi relatif 
Kelurahan Lomanis dalam Kecamatan Cilacap Tengah dapat memudahkan para pemangku kepentingan, warga, pendatang, dan tamu dalam mengenali wilayah Lomanis secara akurat dan eksplisit secara spasial. Selanjutnya, permasalahan mengenai adanya sebagian warga Lomanis yang masih belum memahami orientasi arah ketika berada di Lomanis dapat disebabkan oleh sudut azimuth jalan utama yang membentang di Kelurahan Lomanis (Jalan M.H. Thamrin) memiliki posisi yang tidak tepat lurus utara-selatan maupun barat-timur, melainkan agak serong (Gambar 6). Selain itu, kurangnya wawasan kewilayahan para warga juga berpotensi untuk mengurangi rasa nasionalisme dan kecintaan terhadap kampung halamannya. Permasalahan berikutnya yaitu beberapa data tematik masih belum divisualisasikan dalam bentuk peta sehingga tokoh masyarakat adakalanya mengalami kesulitan dalam menetapkan prioritas kebijakan untuk RW-RW yang ada di Lomanis.

Melalui uraian permasalahan yang telah disebutkan, dapat ditarik benang merah bahwasanya perlu adanya penguatan kapasitas kewilayahan untuk warga Lomanis yang dapat diperkuat melalui beberapa kegiatan pemberdayaan masyarakat dan pengadaan sarana yang menunjang seperti pembuatan peta. Penguatan kapasitas kewilayahan adalah hal yang penting karena kemampuang berpikir spasial adalah hal yang sangat dibutuhkan, terutama di era yang penuh disruspi seperti sekarang ini (Bednarz \& Bednarz, 2008). Penguatan kapasitas kewilayahan yang harapannya bermuara kepada peningkatan kemampuan berpikir spasial warga Lomanis dapat ditunjang melalui kegiatan pengadaan peta dasar dan peta tematik yang dibutuhkan oleh warga, seperti peta administrasi, peta komposisi penduduk, dan peta partisipasi balita dalam kegiatan posyandu.

Adanya peta-peta tersebut dapat memberi banyak manfaat. Pertama, menunjang pembentukan peta kognitif atau peta mental seseorang. Peta kognitif atau peta mental itu sendiri dapat diartikan sebagai representasi lingkungan sekitar yang divisualisasikan dalam kognitif/pikiran seseorang (Tversky, 1993). Peta mental seseorang senantiasa diperbarui oleh wawasan baru yang diperolehnya seiring berjalannya waktu melalui berbagai media seperti melihat peta dan berjalan-jalan mengamati lingkungan secara langsung. Kedua, peta-peta skala besar memberikan banyak manfaat seperti menjadi dasar dalam kajian kekotaan (Hidayati, 2013). Ketiga, dapat memberikan gambaran spasial mengenai kondisi kesehatan lingkungan dan kajiankajian kesehatan lainnya (Wibowo \& Sudarmadji, 2010). Keempat, peta-peta tematik dapat menunjang para pemangku kepentingan dalam perencanaan kebijakan maupun pengambilan keputusan.

Berdasarkan paparan mengenai kondisi dan permasalahan yang ada pada mitra, maka dilakukan berbagai upaya untuk penguatan kapasitas kewilayahan warga Lomanis yang berupa (1) pemetaan partisipatif guna pengadaan peta administrasi Kelurahan Lomanis, (2) pemetaan partisipatif guna pengadaan peta komposisi penduduk Lomanis, (3) pemetaan partisipatif guna pengadaan peta partisipasi balita dalam posyandu, dan (4) lomba mengenal Cilacap dan Negara Kesatuan Republik Indonesia (NKRI) melalui peta untuk anak-anak dan remaja. Keempat tujuan yang telah dipaparkan bermuara pada penguatan kapasitas kewilayahan dan kemampuan berpikir spasial warganya serta menggali potensi yang ada di wilayah tersebut (Amaru, Asdak, \& Balia, 2013). Dengan mengenali lingkungan dan potensi yang ada di wilayah tempat tinggal, maka diharapkan dapat memperkuat rasa nasionalisme dan kecintaan terhadap tanah air. Peta juga dapat digunakan sebagai bagian dari proses manajemen kebencanaan (Rogi, 2017). Selain itu, peta-peta tersebut juga dapat digunakan sebagai bahan pengambilan keputusan maupun mempermudah calon investor yang hendak melakukan kegiatan di Kelurahan Lomanis. Adapun poin 4 yang mana lomba mengenal Cilacap dan NKRI melalui peta, memang sengaja dikhusukan untuk anakanak dan remaja karena penanaman pola berpikir spasial idealnya ditanamkan sedini mungkin (Tversky, 1993). 


\section{Metode}

Program pemberdayaan masyarakat yang telah dilakukan merupakan bagian dari program Kuliah Kerja Nyata (KKN) Pembelajaran Pemberdayaan Masyarakat (PPM). Kegiatan KKN PPM ini merupakan kerjasama antara Lembaga Penelitian Dan Pengabdian Kepada Masyarakat (LPPM) Universitas Gadjah Mada (UGM) dengan mitra yang dalam hal ini Kelurahan Lomanis, Kecamatan Cilacap Tengah, Kabupaten Cilacap Provinsi Jawa Tengah. Kegiatan telah dilaksanakan pada bulan Juli-Agustus 2013. Pada dasarnya kegiatan penguatan kapasitas kewilayahan yang dilakukan memiliki sasaran para anak-anak, remaja, dan dewasa. Penguatan kapasitas kewilayahan pada anak-anak dilakukan melalui lomba mengenal Cilacap dan NKRI melalui peta untuk anak-anak dan remaja.

Adapun alasan pemilihan metode tersebut karena pada dasarnya anak-anak dan remaja memiliki rasa ingin bermain yang tinggi dan beberapa dari mereka cenderung sulit untuk kooperatif jika kemasan kegiatannya monoton seperti ceramah. Lebih lanjut, melalui lomba berhadiah, para peserta kegiatan akan mengikuti kegiatan dengan segenap kemampuan yang dimilikinya sehingga harapannya bermuara kepada peningkatan kapasitas kewilayahan, pola berpikir spasial, dan pemahaman mengenai potensi wilayah yang ada. Pemahaman spasial dan potensi wilayah yang baik dapat menyempurnakan peta mental seseorang sehingga ia memiliki pemahaman tentang citra suatu wilayah dengan baik pula (Purwanto, 2004). Terkait peningkatan kapasitas kewilayah pada orang dewasa, kegiatan pemetaan partisipatif merupakan salah satu bagian dari Participatory Rural Appraisal (PRA). PRA sederhananya merupakan pendekatan partisipatif yang berupa keikutsertaan masyarakat dalam memberi penilaian terhadap kondisi wilayahnya (Chambers, 1994). Pendekatan partisipatif dilakukan supaya warga juga berkontribusi dalam membangun daerahnya sehingga harapannya kecintaan mereka terhadap wilayahnya semakin kuat. Lebih lanjut, penarikan batas RW juga perlu didampingin oleh tokoh masyarakat yang nantinya diverifikasi oleh pihak kelurahan supaya nantinya tidak terjadi konflik atau hal-hal yang tidak inginkan lainnya.

Kegiatan yang pertama yang dilakukan yaitu pembuatan peta administrasi yang didalamnya juga terdapat batas RW Kelurahan Lomanis yang berkolaborasi dengan masyarakat setempat. Pembuatan peta administrasi dilakukan sebagai kegiatan yang pertama karena peta administrasi merupakan data yang bersifat dasar dan menjadi landasan dalam pembuatan peta-peta tematik lainnnya. Pembuatan peta diawali dengan diskusi informal dengan warga sekitar dan tokoh masyarakat mengenai batas-batas RW dan kelurahan-kelurahan yang merupakan tetangga Kelurahan Lomanis. Diskusi informal perlu dilakukan sebagai langkah awal karena diskusi informal merupakan salah satu teknik yang bertujuan meminta izin secara kultural jika kita ingin melakukan sesuatu yang berkenaan dengan masyarakat Jawa.

Tahap selanjutnya dari kegiatan pemetaan batas RW yaitu proses download atau mengunduh citra satelit resolusi tinggi yang diperoleh melalui Google Earth dan data-data peta dasar yang bersumber dari peta Rupa Bumi Indonesia (RBI) skala 1:25.000. Adanya citra satelit dan data batas-batas kelurahan dapat mempermudah tim penulis dan mitra dalam melakukan pemetaan dan penarikan batas-batas RW. Selanjutnya, tim penulis mengunjungi tempat-tempat yang menjadi perbatasan antar RW yang dilanjutkan dengan penarikan batas RW bersama warga setempat. Selain itu, tim penulis juga berkomunikasi dengan pegawai kelurahan untuk memita pendapat mereka sekaligus sebagai sarana pencocokan data. Setalah diperoleh data batas RW yang bersumber dari warga setempat dan pegawai kelurahan, kegiatan dilanjutkan dengan proses memasukkan data ke dalam Sistem Informasi Geografis (SIG). Data-data spasial yang diolah dengan SIG, lalu diproses layouting untuk mendapatkan peta yang sesuai kaidah kartografis yang berlaku umum. Pembuatan peta sesuai kaidah kartografis yang berlaku umum perlu dilakukan 
supaya pembaca tidak salah melakukan intepretasi isi peta yang disajikan sehingga komunikasi kartografis antara pembuat dan pengguna peta berjalan secara efektif, efisien, dan tepat.

Pembuatan peta komposisi penduduk dan peta partisipasi balita dalam posyandu dilakukan secara paralel untuk meminimalkan waktu yang dibutuhkan dalam proses pengerjaan. Tahap awal dilakukan dengan diskusi informal dengan pegawai kantor kelurahan Lomanis seperti yang telah dilakukan pada pembuatan peta adminsitrasi sebelumnya. Selepas diskusi informal, pegawai kantor kelurahan membagikan data monografi Kelurahan Lomanis, yang di dalamnya terdapat data komposisi penduduk dan tingkat partisipasi balita dalam kegiatan posyandu untuk masingmasing RW. Data ini merupakan data yang sangat penting dalam menunjang berbagai kegiatan dalam skala lokal dan data monografi tingkat kelurahan juga belum dipublikasikan secara daring.

Setelah diperoleh data yang dibutuhkan terkait komposisi penduduk dan tingkat partisipasi balita dalam kegiatan posyandu untuk masing-masing RW, dilakukan proses input data ke dalam SIG. Pada proses pembuatannya, membutuhkan upaya dalam memilih desain peta yang tepat karena jika desain peta tidak dapat maka berpotensi untuk terjadinya kesalahan interpretasi oleh pengguna peta. Selain itu, desain peta yang kurang sesuai juga dapat menghambat proses komunikasi kartografis antara pembuat dan pengguna peta sehingga transfer informasi dari pembuat peta kepada pengguna peta tidak berjalan lancar. Selanjutnya, peta yang sudah didesain dilakukan proses layouting sesuai dengan kaidah kartografis yang berlaku umum. Sebagai tahap akhir, peta-peta dasar dan tematik yang telah dibuat diberi pigura sehingga bisa dipajang di kantor kelurahan untuk berbagai keperluan seperti perencanaan, pengambilan keputusan, dan memberi gambaran kepada calon investor mengenai kondisi Kelurahan Lomanis secara spasial.

Terkait pelaksanaan lomba mengenal Cilacap dan NKRI melalui peta dilakukan dengan kegiatan awalan berupa nonton film bersama dengan tema pengenalan berbagai macam bencana. Pengenalan berbagai macam bencana yang dikemas melalui nonton film merupakan hal yang sangat penting dalam mengenal potensi bencana yang terjadi di lingkungan sekitar. Media pemutaran film dipilih supaya dapat menarik anak-anak dan remaja untuk mengikuti kegiatan. Kegiatan selanjutnya yang merupakan kegiatan inti yaitu lomba mengenal Cilacap dan NKRI melalui peta. Teknisnya, kegiatan diawali dengan pembagian peta buta Cilacap (peta tanpa label informasi) yang di dalamnya terdapat batas-batas kecamatan yang ada di Kabupaten Cilacap. Peserta lalu diminta untuk mempelajari peta buta yang ada dihadapan mereka. Selanjutnya, peserta diminta untuk berkompetisi dalam menjawab nama kecamatan-kecamatan yang diajukan oleh tim penulis. Peserta dengan paling banyak menjawab nama-nama kecamatan dengan benar akan meraih skor tertinggi dan dinyatakan sebagai pemenang. Kegiatan dilanjutkan dengan pengenalan NKRI menggunakan peta buta yang di dalamnya terdapat berbagai provinsi yang ada di Indonesia. Teknis lombanya serupa dengan teknis lomba untuk mengenal Kabupaten Cilacap.

\section{Hasil dan Pembahasan}

Pelaksanaan kegiatan pembuatan peta administrasi Kelurahan Lomanis secara partisipatif dengan warga setempat berjalan lancar. Kelancaran proses pembuatan peta adminstrasi Lomanis (Gambar 6) juga ditunjang oleh adanya anggota tim yang merupakan warga lokal sehingga bisa memahami bahasa lokal setempat dan mudah melakukan negosiasi dengan warga (Gambar 1). Kegiatan pemetaan partisipatif ini merupakan kegiatan yang bersifat iteratif karena dalam prakteknya tidak langsung sekali jadi, namun dibutuhkan beberapa proses revisi dan klarifikasi dengan berbagai elemen masyarakat seperti warga RW yang berbatasan dan pegawai kelurahan. Pemetaan dalam KKN ini bisa berjalan dengan baik walau terdapat seperti misalnya batas antara wilayah RW 4 dengan RW 5 sangat sulit untuk dipetakan karena yang menjadi batas adalah 
rumah, bukan jalan atau selokan seperti di RW yang lain. Namun permasalahan tersebut berhasil diatasi berkat Global Positioning System (GPS) yang terdapat pada smartphone.

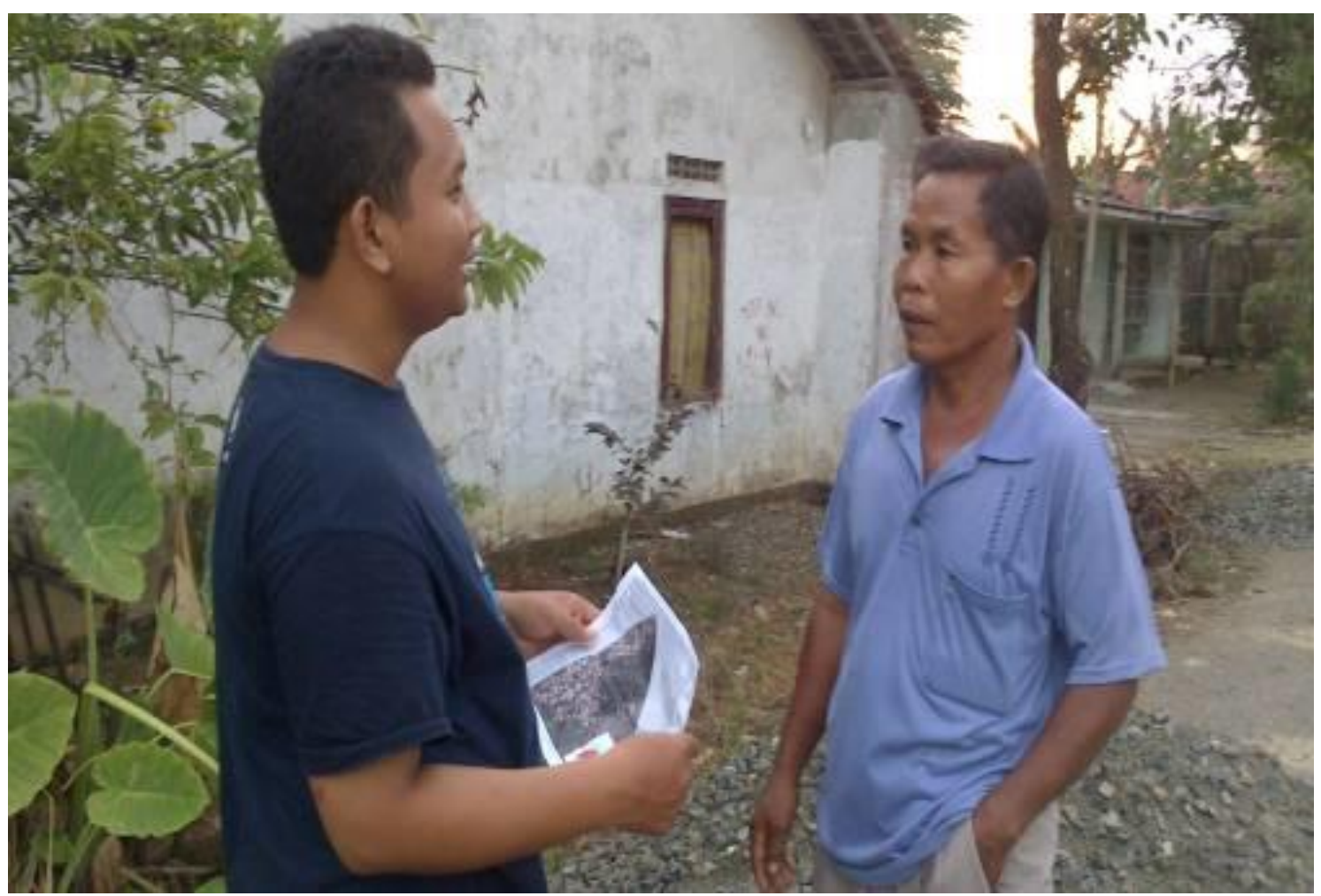

Gambar 1. Diskusi antara warga setempat dengan anggota tim penulis ketika proses pemetaan batas RW secara partisipatif.

Pembuatan peta berbasis SIG sangat memudahkan dalam pemetaan wilayah dengan bantuan teknologi digital (Rini, Derita, \& Endayani, 2015). Terlebih SIG memiliki kemampuan untuk mengintegrasikan data spasial dari berbagai sumber yang dapat disajikan menjadi peta yang merupakan hasil integrasi dari berbagai data spasial penyusunnya (Kraak \& Ormeling, 2010). Hal unik yang ditemui yaitu ternyata banyak masyarakat yang belum mengetahui seberapa sempit wilayah permukiman dan seberapa luas wilayah yang digunakan sebagai kawasan industri. Selain itu, melalui peta yang dibuat, masyarakat menjadi semakin paham mengenai arah orientasi spasial. Pemahaman akan orientasi spasial akan banyak memiliki manfaat seperti dalam mencari jalan terobosan dan menentukan arah kiblat. Peta yang telah dibuat berhasil memudahkan para warga dalam membangun peta mental mengenai kondisi lingkungan sekitar tempat tinggal warga. Lebih lanjut, peta administrasi batas RW juga memudahkan bagi pendatang dalam melakukan rapid assessment (penilaian cepat) terhadap kondisi Lomanis secara spasial.

Pelaksanaan agenda pembuatan peta tematik berupa peta komposisi penduduk (Gambar 7) dan peta tingkat partisipasi balita dalam kegiatan posyandu (Gambar 8) yang telah dilaksanakan secara partisipatif dengan warga setempat berjalan dengan lancar. Kelancaran proses pembuatan peta-peta tematik tersebutjuga ditunjang oleh sifat kooperatif dan antusiasme pegawai kantor Kelurahan Lomanis dalam memberikan rekapitulasi data yang dibutuhkan (Gambar 2). Kegiatan pemetaan partisipatif ini merupakan kegiatan yang bersifat iteratif karena dalam prakteknya tidak langsung sekali jadi, namun dibutuhkan beberapa proses revisi untuk mendapatkan desain peta tematik yang paling ideal berdasarkan kondisi yang ada. Adapun kendala yang dihadapi yaitu data 
tentang penduduk dan tingkat partisipasi balita yang sudah out of date. Data yang ada di kelurahan yang sudah direkap yaitu data tahun 2011. Sedangkan data tahun 2012 dan 2013 belum direkap oleh pihak kelurahan. Tim penulis akhirnya hanya membuat peta berdasarkan data pada tahun 2011 karena untuk merekapitulasi data hingga tahun 2013 dibutuhkan waktu yang sangat lama.

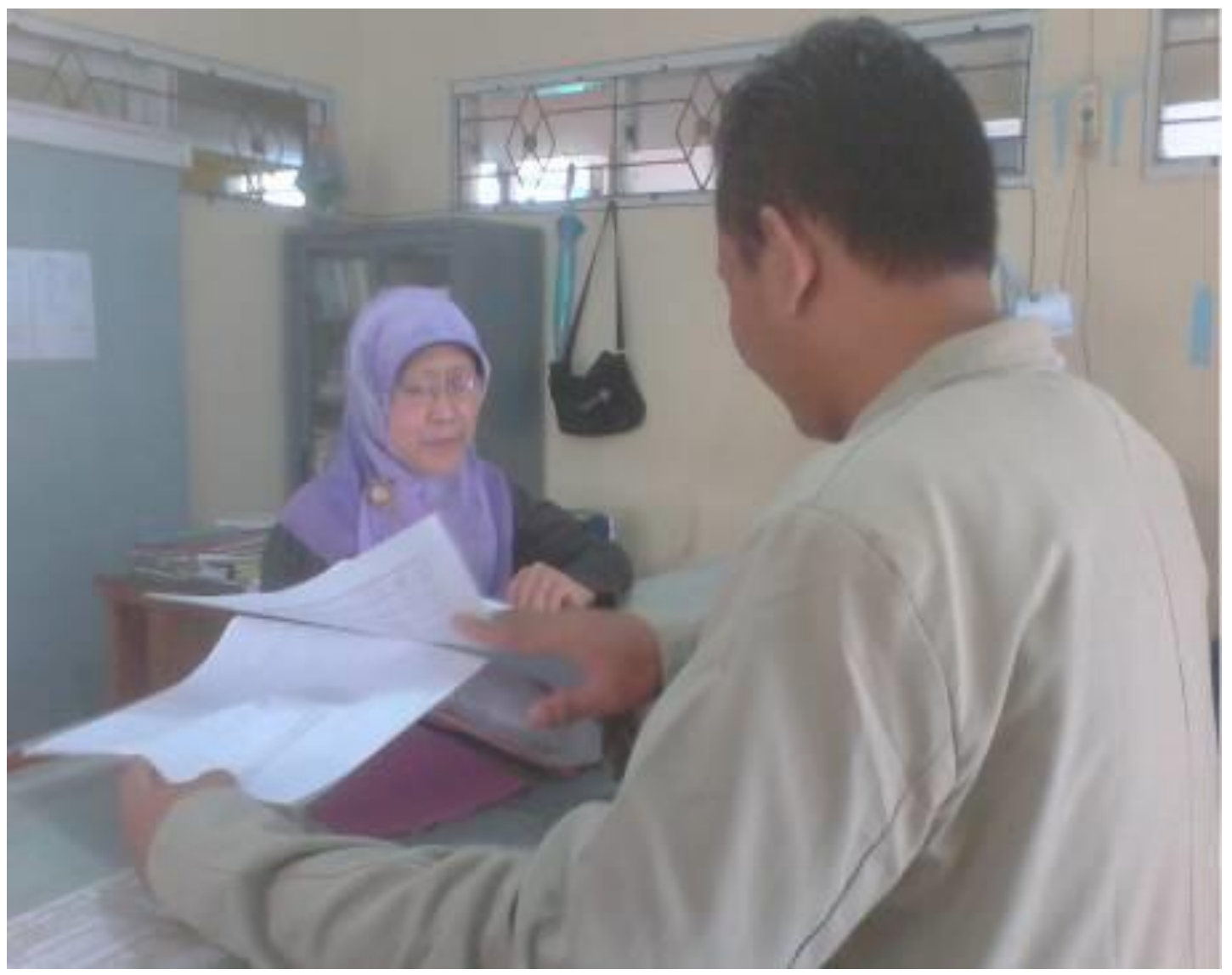

Gambar 2. Proses akuisisi data-data tematik secara partisipatif dengan pegawai kantor Kelurahan Lomanis.

Peta yang dibuat secara partisipatif dapat menstimulus pemahaman warga dalam aspek kewilayahan sehingga dapat meningkatkan kesadaran mengenai potensi dan permasalahan yang ada di suatu wilayah (Baharudin \& Amri, 2020). Melalui peta komposisi penduduk, warga dan pendatang dapat mengetahui bagaimana dinamika spasial terkait kondisi demografi di Kelurahan Lomanis. Berdasarkan hasil pengamatan dan observasi, diperoleh fakta bahwa di Kelurahan Lomanis terdapat potensi demografi yang berupa banyaknya angkatan kerja. Namun, apabila potensi tersebut tidak dikelola dengan baik malah akan menjadi masalah seperti pengangguran, konflik horizontal, dan kenakalan remaja Adapun peta tingkat partisipasi balita dalam kegiatan posyandu juga dapat menjadi landasan bagi pegawai Kelurahan dalam melakukan perencanaan dan pengambilan kebijakan terkait kondisi posyandu di masing-masing RW. Adanya peta yang dapat menunjukan sebaran tingkat partisipasi balita secara eksplisit juga memudahkan kader posyandu dalam mengevaluasi kegiatan yang selama ini telah dilakukan. Berkat adanya peta-peta tematik tersebut, kompetensi warga setempat terkait aspek kewilayahan dan kemampuan memahami wilayanya secara spasial menjadi meningkat. 
Kegiatan lomba mengenal Cilacap dan NKRI melalui peta dilaksanakan dengan kegiatan pendahuluan berupa pengenalan berbagai macam bencana yang ada di Indonesia. Tidak seperti kegiatan-kegiatan pemetaan partisipatif yang cenderung melibatkan warga yang dewasa, pada kegiatan ini lebih menyasar kepada anak-anak dan remaja mengingat pendidikan seputar kewilayahan perlu dikenalkan sejak dini (Tversky, 1993). Kegiatan pengenalan konsep bencana dan macam-macam bencana yang ada di Indonesia melalui media film sehingga para peserta menikmati jalannya acara dan secara tidak sadar telah belajar berbagai konsep kewilayahan (Gambar 3). Pemahaman tentang bencana merupakan hal yang sangat penting, apalagi Indonesia merupakan negara yang rawan terhadap berbagai bencana (Subanti, Hakim, Lestari, Pratiwi, \& Hakim, 2019).
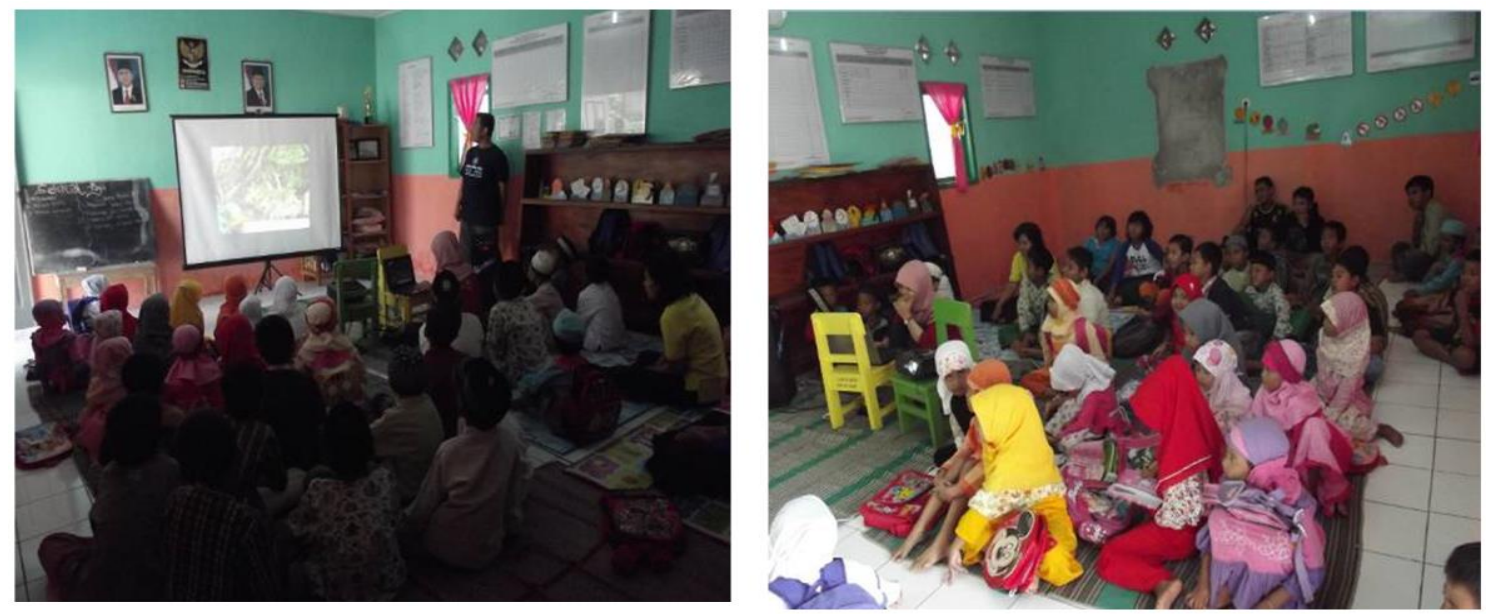

Gambar 3. Suasana saat kegiatan pemutaran film tentang kebencanaan yang membuat banyak peserta antusias.

Beberapa hari setelah pengenalan konsep kebencanaan, agenda dilanjutkan dengan lomba mengenal Cilacap dan NKRI melalui peta. Adanya lomba ini merupakan upaya tim penulis untuk meningkatkan kompetensi kewilayahan anak-anak sejak dini menggunakan cara yang menyenangkan (Gambar 4 dan Gambar 5). Kegiatan ini berjalan sangat lancar dan meriah karena anak-anak berkompetisi dengan sangat antusias. Melalui kegiatan lomba seperti ini, anak-anak secara tidak sadar sedang mempelajari dinamika kewilayahan secara spasial pada skala lokal (Kabupaten Cilacap) maupun skala nasional (NKRI). Selain itu, kegiatan ini juga sebagai sarana untuk mengasah integritas dan aspek sportivitas pada anak-anak sejak dini. Sportivitas anak-anak diuji sini. Ketika kegiatan dilaksanakan, tidak ditemukan satupun kasus kecurangan yang dilakukan dalam memenangkan lomba yang menandakan anak-anak di Kelurahan Lomanis memiliki nilai-nilai kejujuran yang tinggi. Setelah dilaksanakan program ini, ternyata diketahui bahwa banyak peserta yang kurang mengenal wilayahnya sendiri terutama kecamatan-kecamatan yang ada di Kabupaten Cilacap. Selain itu, mereka juga kurang mengenal provinsi-provinsi yang ada di NKRI beserta ibukotanya. Peserta mendapat pencerahan bahwa mengenal NKRI adalah modal awal dalam mempertahankan NKRI dan meningkatkan rasa nasionalisme. 


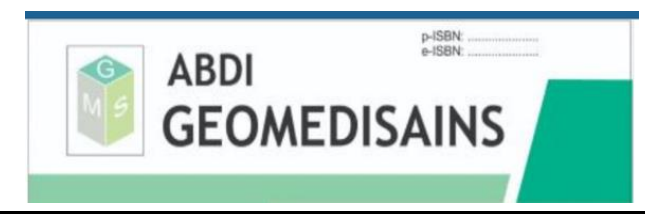

Abdi Geomedisains, Vol 1 (1) Juli 2020:1-14

DOI: $10.23917 /$ abdigeomedisains.v1i1.91

(C) Author(s) 2020. CC BY-NC-ND Attribution 4.0 License http://journals2.ums.ac.id/index.php/abdigeomedisains/

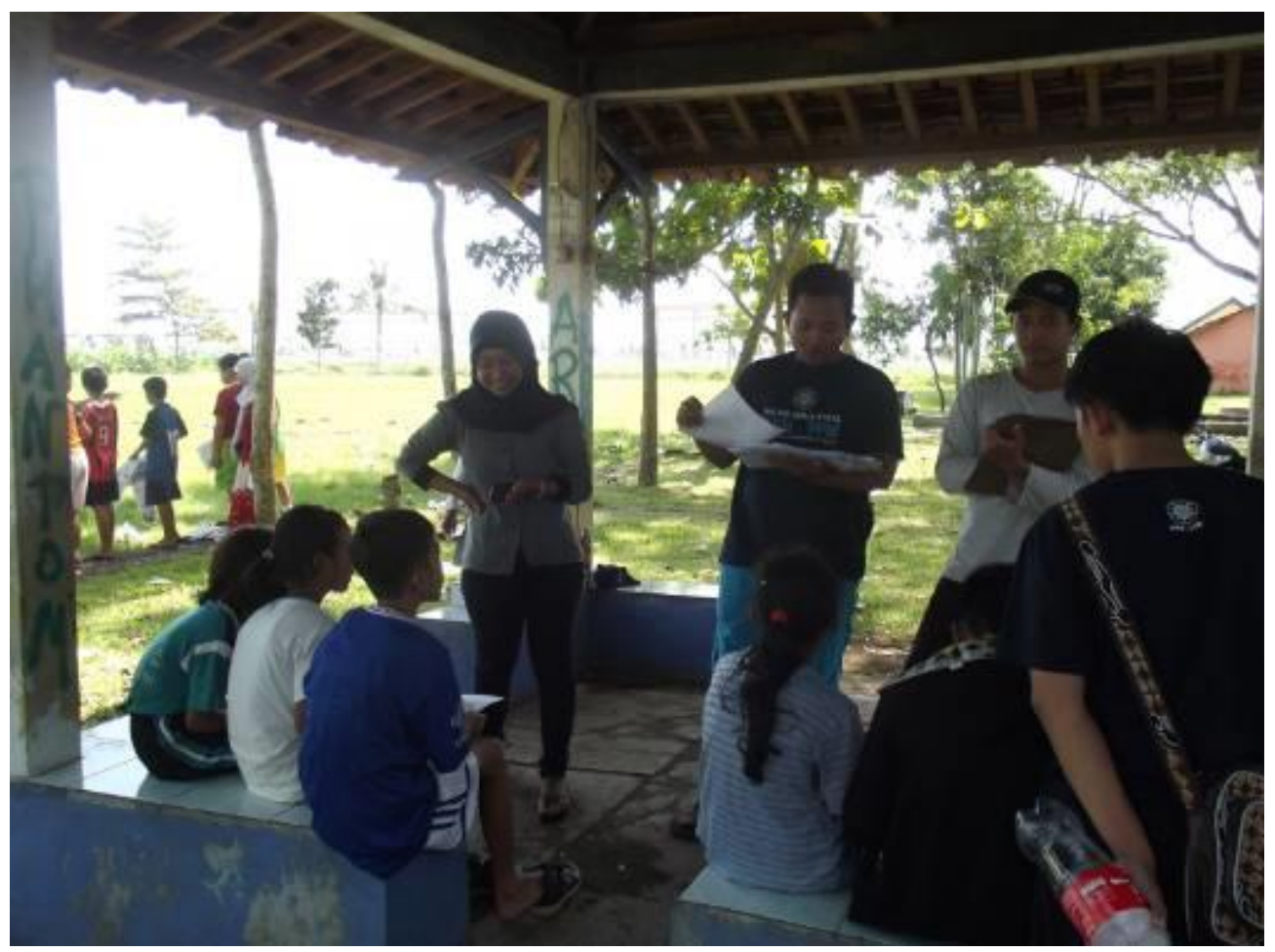

Gambar 4. Penyampaian teknis pelaksanaan lomba. Terlihat para peserta amat memperhatikan teknis lomba yang disampaikan.

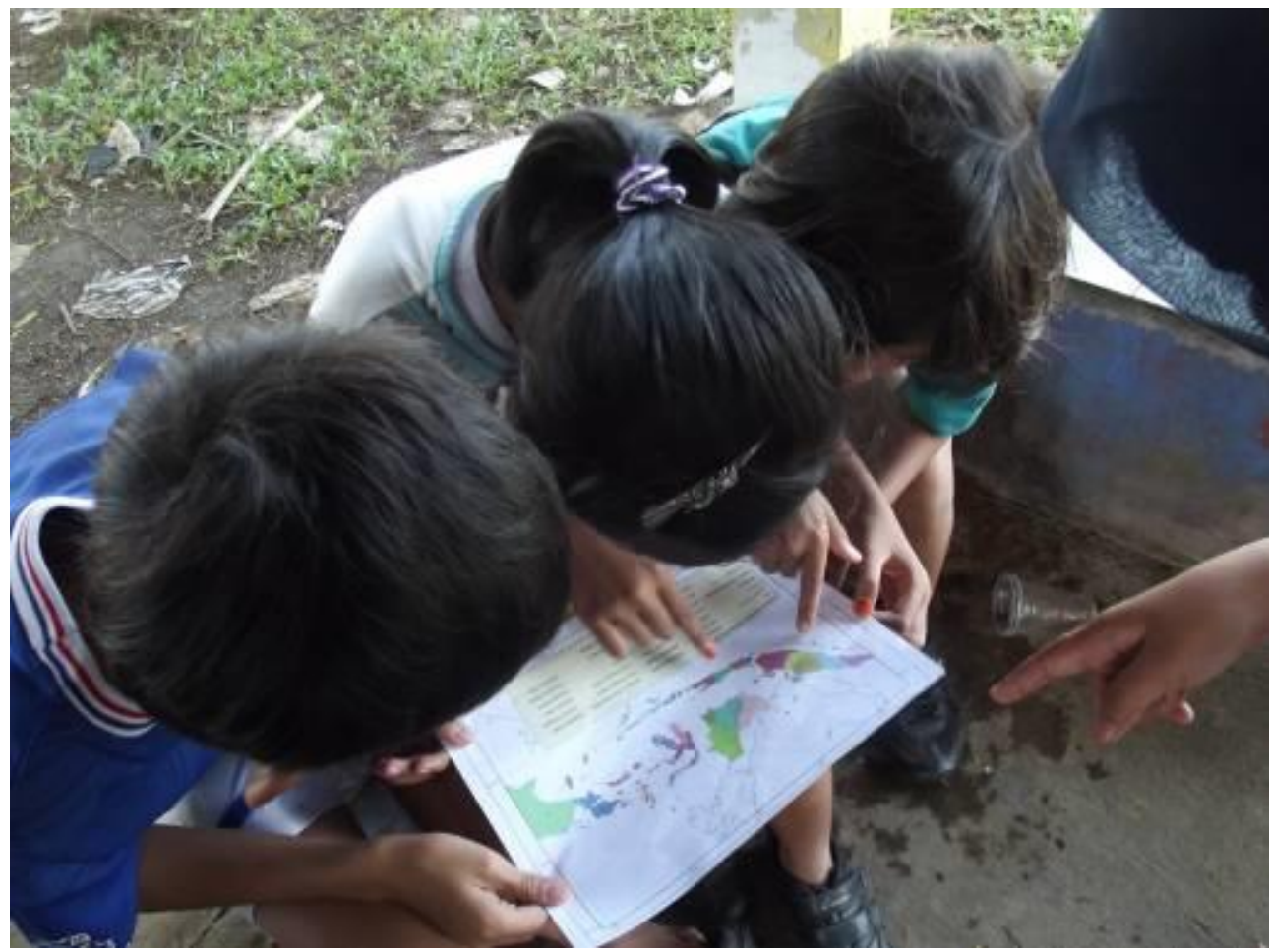

Gambar 5. Suasana saat kompetisi mengenal NKRI melalui peta. Terlihat anak-anak sedang mencari informasi mengenai provinsi dan ibukota yang ditanyakan oleh tim penulis. 
Secara keseluruhan, seluruh pelaksanaan kegiatan kolaboratif antara tim penulis dengan warga setempat berjalan lancar. Peta dasar seperti peta administrasi yang memuat batas RW dan peta-peta tematik seperti peta komposisi penduduk dan peta tingkat partisipasi balita dalam posyandu memiliki banyak manfaat dalam berbagai aspek seperti pembuatan perencanaan kebijakan, pengambilan keputusan, meningkatkan pemahaman warga terkait dinamika spasial yang ada di Lomanis dan memudahkan para pendatang dalam mengenali kondisi lingkungan Lomanis secara cepat. Pemahaman mengenai potensi dan permasalahan yang ada di lingkungan sekitar menjadi modal penting dalam membangun rasa nasionalisme dan cinta tanah air. Kegiatan pendampingan seperti ini perlu dilakukan secara berkala dan dapat diterapkan di Kelurahankelurahan lainnya.

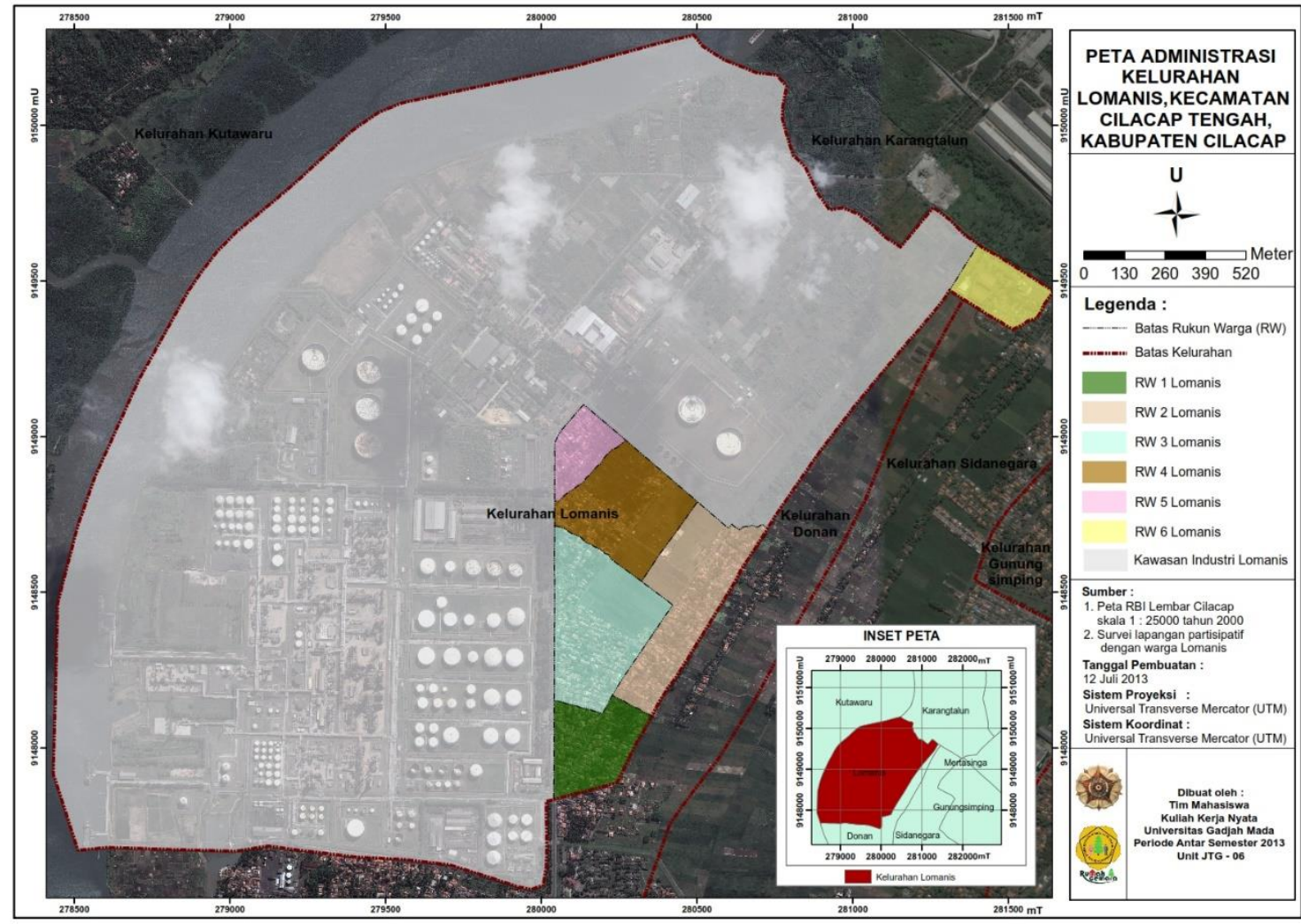

Gambar 6. Peta administrasi Kelurahan Lomanis yang memuat batas-batas RW yang dibuat secara partisipatif dengan berbagai elemen masyarakat. 


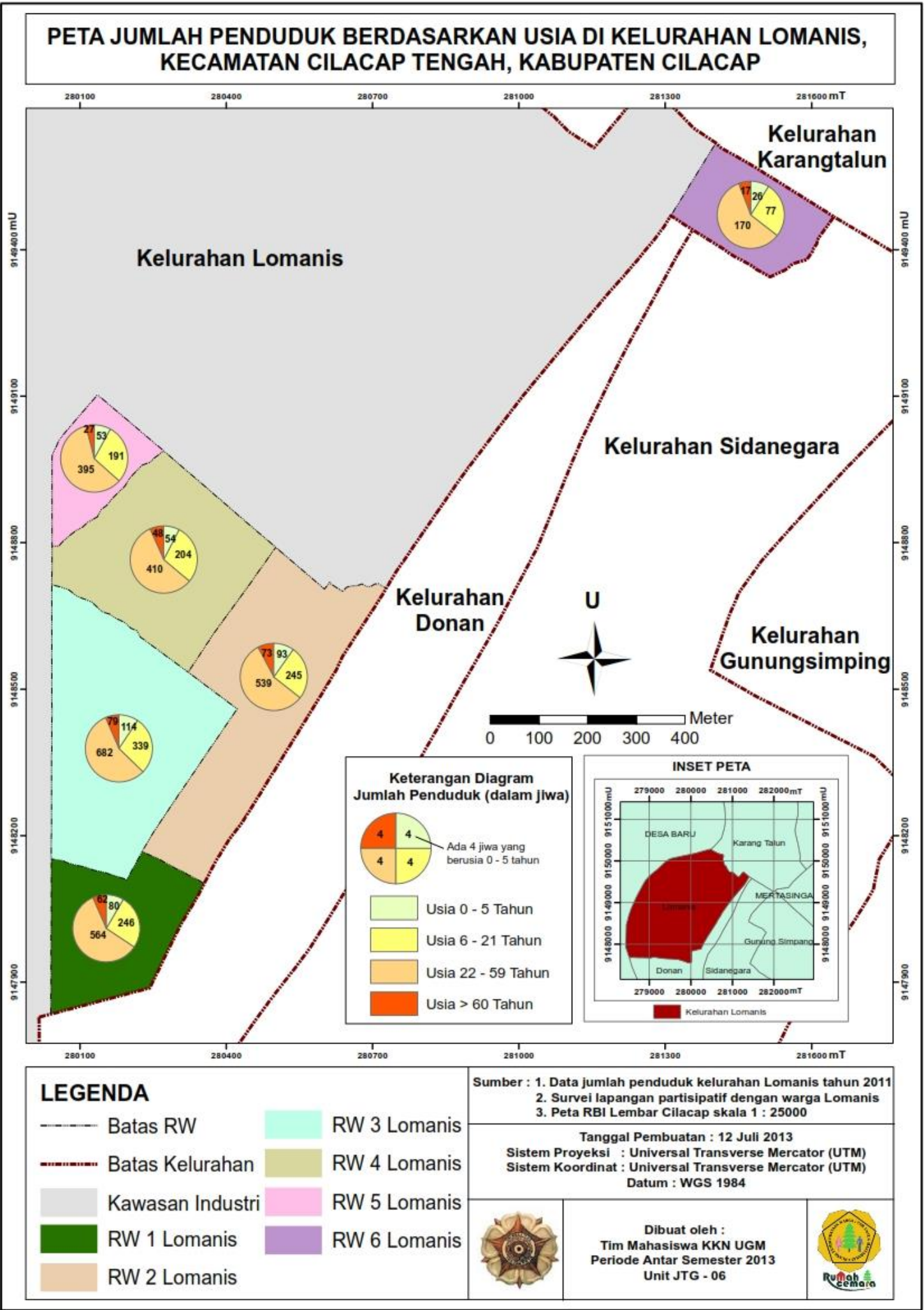

Gambar 7. Peta komposisi penduduk di Kelurahan Lomanis yang dibuat secara partisipatif dengan berbagai elemen masyarakat. 


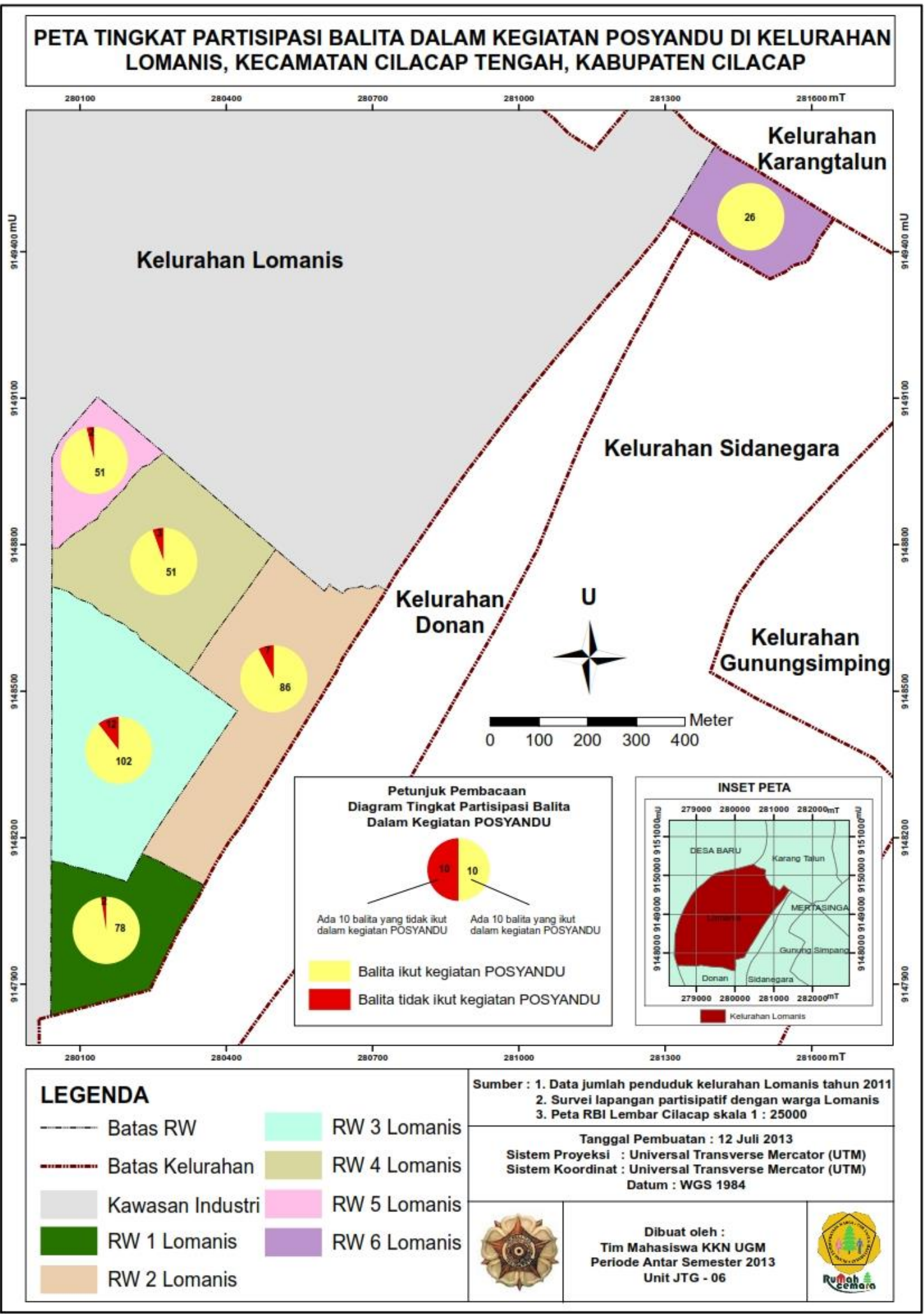

Gambar 8. Peta tingkat partisipasi balita dalam kegiatan posyandu di Kelurahan Lomanis yang dibuat secara partisipatif dengan berbagai elemen masyarakat. 


\section{Simpulan}

Upaya penguatan kapasitas kewilayahan masyarakat Kelurahan Lomanis yang dikemas melalui berbagai kegiatan berjalan dengan lancar. Pembuatan peta-peta secara partisipatif baik peta dasar yang memuat batas RW dan peta-peta tematik seperti peta komposisi penduduk dan peta tingkat partisipasi balita dalam kegiatan posyandu memberikan banyak manfaat. Masyarakat menjadi semakin paham mengenai dinamika yang ada di lingkungan tempat mereka tinggal secara spasial. Adapun kegiatan lomba mengenal Cilacap dan NKRI melalui peta juga mendapatkan respon yang sangat baik dari peserta. Yang tidak kalah penting yaitu para peserta secara tidak sadar telah melakukan proses belajar aspek wilayah pada tingkat lokal (Kabupaten Cilacap) dan nasional (NKRI). Lebih lanjut, anak-anak di Kelurahan Lomanis juga mendapatkan wawasan kebencanaan melalui media film sehingga peserta menikmati proses pembelajaran kewilayahan dengan cara yang menyenangkan. Kegiatan pemberdayaan seperti ini baiknya juga diterapkan di kelurahan-kelurahan lainnya sebagai upaya dalam mengenali potensi dan permasalahan yang ada di suatu wilayah yang mana nantinya diharapkan dapat bermuara pada meningkatnya rasa nasionalisme dan cinta tanah air. Saran untuk kegiatan pengabdian selanjutnya adalah harus diupayakannya terdapat warga lokal yang membantu mengkomunikasikan maksud dan tujuan dari tim yang akan melakukan pemberdayaan masyarakat dengan para warga lokal setempat.

\section{Persantunan}

Ucapan terima kasih penulis ucapkan kepada berbagai pihak yang telah bersedia untuk bekerjasama dalam rangka pelaksanaan kegiatan. Terima kasih kepada Lembaga Penelitian Dan Pengabdian Kepada Masyarakat (LPPM) UGM yang telah menyediakan kesempatan kepada tim penulis untuk mengamalkan salah satu Tri Dharma perguruan tinggi. Ucapan terima kasih juga penulis sampaikan kepada para pegawai Kelurahan Lomanis yang telah banyak membantu tim penulis dalam menjembatani berbagai keperluan dan kegiatan yang dilaksanakan bersama warga. Tim Penulis juga sangat berterima kasih atas kesediaan warga Kelurahan Lomanis, khususnya RW 2 dan RW 6 yang telah meluangkan waktu dan tenaga untuk bersama-sama mensukseskan kegiatan pengutan kapasitas masyarakat.

\section{Referensi}

Amaru, K., Asdak, C., \& Balia, R. (2013). Penyuluhan pengenalan peta dan identifikasi potensi daerah untuk pembuatan peta potensi desa di Desa Jatimekar dan Desa Cijati Kecamatan Situraja Kabupaten Sumedang. Dharmakarya, 2(1), 32-40.

Baharudin, \& Amri, U. (2020). PKM Pemetaan Partisipatif Kawasan Ekowisata Mangrove Di Desa Pagatan Besar Kabupaten Tanah Laut Propinsi Kalimantan Selatan. Jurnal Maritim, $1(2), 59-67$.

Bednarz, R. S., \& Bednarz, S. W. (2008). The Importance of Spatial Thinking in an Uncertain World. In D. Z. Sui (Ed.), Geospatial Technologies and Homeland Security: Research Frontiers and Future Challenges (pp. 315-330). Dordrecht: Springer Netherlands.

BPS Cilacap. (2014). Kecamatan Cilacap Tengah Dalam Angka Tahun 2014. Cilacap: Badan Pusat Statistik Cilacap.

Chambers, R. (1994). The origins and practice of participatory rural appraisal. World Development, 22(7), 953-969. doi:https://doi.org/10.1016/0305-750X(94)90141-4

Ekaputri, C. S. M. A. (2014). Rumah Cemara: Ruang Multi Aktor Dalam Pengembangan Program CSR. (skripsi S1 yang tidak dipublikasikan), Universitas Gadjah Mada, Yogyakarta.

Hidayati, I. N. (2013). Analisis Harga Lahan Berdasarkan Citra Penginderaan Jauh Resolusi Tinggi. Jurnal Gea, 13(1), 57-71. 
Kraak, M. J., \& Ormeling, F. (2010). Cartography: Visualization of Geospatial Data 3rd Edition. Essex: Pearson Education Limited.

Purwanto, E. (2004). Pendekatan Pemahaman Citra Lingkungan Perkotaan (melalui kemampuan peta mental pengamat). Dimensi, 29(1).

Rini, Derita, D., \& Endayani, S. (2015). Pemetaan Tata Batas Secara Partisipatif Setelah Pemekaran Dengan Aplikasi Sistem Informasi Geografis di Kelurahan Bugis Kecamatan Samarinda Kota. Agrifor, 14(1), 95-102.

Rogi, O. H. A. (2017). Peta Kebencanaan: Urgensi dan Manfaatnya. Media Matrasain, 14(3), 6176.

Subanti, S., Hakim, A. R., Lestari, E. P., Pratiwi, H., \& Hakim, I. M. (2019). Measuring the economic value of disaster mitigation on quality of life in Indonesia. Journal of Physics: Conference Series, 1341, 092002. doi:10.1088/1742-6596/1341/9/092002

Tversky, B. (1993). Cognitive maps, cognitive collages, and spatial mental models. Paper presented at the Spatial Information Theory A Theoretical Basis for GIS, Berlin, Heidelberg.

Wibowo, A., \& Sudarmadji, B. W. (2010). Peta Skala Besar (Batas RW) dan Manfaatnya. Majalah Ilmiah Globe, 12(1).

\section{(c) (1) $(9)$}

(C) 2020 by the authors. Submitted for possible open access publication under the terms and conditions of the Creative Commons Attribution (CC-BY-NC-ND) license (http://creativecommons.org/licenses/by/4.0/). 